\title{
Fostering the Citizen Participation Models for Public Value Creation in Cooperative Environment of Smart Cities
}

\author{
Manuel Pedro Rodríguez Bolívar ${ }^{1}$ \\ ${ }^{1}$ University of Granada, Granada, 18071, Spain \\ manuelp@ugr.es
}

\begin{abstract}
The growth of smart cities is forcing governments to focus their efforts on the increase of public value creation. Based on prior research, on the perception of smart city practitioners and on an empirical observation, this paper seeks to analyse the public value creation under the context of the smart cities, examining the model of citizen participation and the use of new technologies by city governments in smart cities with the aim at improving eparticipation of the citizenry in the public arena. Findings indicate the need for using new technologies to adopt a more participative model of governance, although, nowadays, sample smart cities are not putting available technological tools or promoting citizens to be involved in online public consultations, discussions and petitions.
\end{abstract}

Keywords: Public Value Creation; Creative Citizenship; Smart Governance; Smart Cities.

\section{Introduction}

Public value creation has become a main domain of the smart city (SC) phenomenon [15] and introduces a more holistic approach to city governance, with the implementation of new and innovative forms of city governance based on the concept of network governance and pursuing the achievement of citizen-centric projects [16]. The smart governance is not therefore built on what governments do but about the outcomes of interactions between all actors in the public domain seeking for a common purpose and strategic priorities, in brief, in the pursuit of public value goals [20].

Civic participation is thus seen as a main way of transforming government to make it open and closer to the citizenry needs under the context of smart cities and the smart cities movement has promoted the creation of places where relational networks of actors are produced, constituting the urban governance as a crucial axis of smarter cities, since they reflect how public value can be generated with the participation of citizens and other social actors [11] and highlights the process of coordinating and steering the urban society toward collectively defined goals [17]. Nonetheless, up to now, there is a lack of research regarding the analysis of the relevance that smart cities associate to collaborative governance models as well as whether smart cities are 
using e-participation tools to promote the citizen involvement in the public affairs of the city.

This paper contributes to the advance of the knowledge of public value creation analysing the model of citizen participation in smart cities and the use of tools for improving e-participation in these cities. To achieve this aim, this paper analyses a sample group of smart cities that are members of the EUROCITIES network and seeks to examine the model of citizen participation and to find whether perceptions about smart governance models (e-survey) are coming true into real political intentions in smart cities through the offer of e-participation tools for citizen involvement.

The remainder of the paper is as follows. Next section describes the public value creation in smart cities based on building participative governance of the cities and after that, an empirical research on sample cities that are members of the EUROCITIES network is performed, especially in those that promote cooperation engaging and empowering citizens to help make their cities 'smarter' [5]. Then, the data and method used in this research are described and each one of the research questions proposed in this paper is analysed through the lens of the results of our study. Finally, the conclusions and discussions section brings this paper to an end.

\section{Fostering Public Value Creation in Smart Cities through Cooperative Environments}

A growing urban development and reforms and innovations in new technologies have produce challenges of innovation in city governance [25] with the aim at facing new challenges of the current society. These new urban structures have been based on the use of non-hierarchical, non-market forms of organization in the public sector [3], built over an intensive use of new technologies. The availability of these ubiquitous ICT infrastructures has stimulated the advance on new citizen-centric services [12] and the creation of cooperative environments to achieve problem-solving and innovation processes [18], creating an integrated approach of the smart cities where governance among stakeholders is converted into the main cornerstone of the smart cities [10]. It has brought the creation of public value into a lively debate in the current political and public sector management arena in smart cities.

Under this framework, European Commission [26] has recognised that by mobilising citizens at local level to debate on concrete issues from the European political agenda will promote civic participation in the EU policy making process and develop opportunities for societal engagement. Indeed, there are no 'smart cities' without 'smart citizens', adding challenges around engaging and empowering citizens to help make their cities 'smarter' [5]. In this regard, under cooperative environments of smart cities [14], cities engage different kinds of knowledge, and encourage widespread public participation to deal imaginatively with complex issues and offers direct association with technological innovation and communal interaction [13]. Thus, city governments should promote citizen involvement in policy making as well as in the implementation of innovative processes and instruments designed to enhance govern- 
ance and public value creation in European cities, especially under the smart cities' framework [9].

Nonetheless, prior research has concluded that city governments far from using new technologies to promote the participation of citizens in public affairs, usually use them as other means of communication, mainly linked to promote cultural events, tourism in the city or, even, as a city branding strategy -representation strategy- [21]. In addition, although the use of participatory innovations has expanded vastly around the world, these new channels for participation have become popular as add-ons to established channels and have been mainly focused on elections and participatory budgeting [27]. Therefore, the following research question is derived:

RQ1. Have governments in smart cities that are involved in projects about cooperative environment of smart cities put available e-participation tools for promoting the collaborative or participative models of governance as a way of public value creation?

According to prior research [20] smart practitioners think that city governments should act as leaders in innovation policies and actions. Nonetheless, the smart city is a city that emerges like an innovation ecosystem [4], where intensive civic participation is an essential ingredient of radical and sustainable innovation [8].

Acting with the creation of government transparency and open data websites, and making data and information available, city authorities support crowd-creation and production of ideas and solutions. It fosters the citizen involvement in public decisions guaranteeing an open and egalitarian approach among stakeholders. Therefore, it is expected to find an association between those smart cities that are prone to stakeholder involvement (selected or open stakeholder participation) and those that have created government transparency and open government data websites to disclose information for reaching out to the civil society in order to base their decisions on this information. So, the following research question is derived:

RQ2. Is the information transparency of governments through the creation of transparency and open government data websites associated with those cooperative environments of smart cities that are more prone to governance models based on selected or open stakeholder participation?

Finally, in cooperative environments of smart cities, intensive civic participation is an essential ingredient of radical and sustainable innovation [8]. To achieve this aim, smart cities are creating collaborative environments using tools like the creation of eparticipation platforms or putting available tools for contacting with the government, in order to involve citizenry in public consultations, discussions and petitions. Therefore, the last research question of this research is:

RQ3. Is the active participation through the creation of participation platforms or tools for contacting with the government associated with those cooperative environments of smart cities that are more prone to governance models based on selected or open stakeholder participation? 


\section{Data and Method}

\subsection{Data collection}

The data of this paper was gathered using two different data collection methods. The first one is based on a questionnaire sent to all representatives of local governments labelled as "smart cities" that are members of the EUROCITIES network to capture their perceptions about smart governance and models of participation in smart cities see table 1 in Appendix-. The EUROCITIES network is the network of over 180 elected local and municipal governments of largest European cities and 40 partner cities, which between them govern 130 million citizens across 35 countries (see $\mathrm{http} / / /$ www.eurocities.eu/eurocities/about_us) and is aimed at reinforcing the role of local governments in a multilevel governance structure, identifying some of the challenges and opportunities in cities that are closely linked to developments at EU level [6]. Therefore, the whole questionnaire of our main research was sent to 70 leading smart cities in Europe -those involved in smart projects into working groups- and 64 responses were received ( $91,42 \%$ of sample smart cities).

Finally, this research has focused on smart cities that are labelled as full member and associate member into the working groups of "Creative citizenship" and "Integrated urban development" included in the area of cooperation. These groups are addressed to improving the city through the co-creation of solutions to local challenges using an integrated urban development, planning and governance. This third data collection method of this paper explores whether these smart cities have created official web pages for government transparency, open data or e-participation platforms. The total sample selection is 85 cities of 165 cities included into the area of cooperation $(51,51 \%)$ or of 184 smart cities included in all areas of EUROCITIES network $(46,19 \%)$.

Whereas the second collection method is addressed to answer RQ1 of this paper, joining the all data collection methods, this paper presents the results obtained for RQ2 and 3.

\subsection{Method}

Under the e-survey analysis, this paper presents only one question included in a wider research which designed an online questionnaire about the importance of collaborative governance in smart cities, the key pillars and outcomes of the concept of smart governance and the model of participation in developing a smart city. For the particular case of this paper, the selected question of the questionnaire was answered with Yes/No responses to each one of the items included in this question -see table 1 in Appendix- and only one answer was allowed for each item. Also, a presentation letter was sent to explain each of the items as well as the rules of the survey and the email provided to ask for doubts about the questionnaire. The question and the presentation letter were translated into the different languages and distributed to the selected sample of smart cities. The results of this part of the questionnaire could help to characterize the participation models in sample smart cities. 
Finally, the third data collection method gathers information about an examination of 85 smart cities (those included in the working groups of "creative citizenship" and "integrated urban development" in the EUROCITIES network) during December of 2017 with the specific purpose of collecting data about smart technologies used for information transparency and active participation. A content analysis was conducted in each one of these websites to observe the presence, or not, of specific websites for e-participation and the issues that are dealt with into each one of the smart technologies analysed. As some websites are only performed in the official language of the city (different from English language), we have used Google translator to read them appropriately.

As for the hypothesis testing for answering RQ2 and RQ3, as all attributes are based on qualitative attributes, the Pearson Chi-Square test was chosen to check the association between responses obtained in the e-survey previously mentioned and the technological tools offered by sample smart cities to achieve government transparency and citizen participation. This methodology of research has been broadly recognized in many research studies as the best statistical tool to test hypotheses of independence for $\mathrm{r} x \mathrm{c}$ contingency tables in which row and column categories are both nominal and mutually exclusive categories [28, 29]. Also, contingency tables were performed to gain an overview of the distribution of the attributes. The research questions were tested at the 0,05 significance level.

\section{$4 \quad$ Result analysis and discussions}

\subsection{Collaborative or participative models of governance in smart cities as a way of public value creation and new technologies used for improving e- participation}

According to the results of our questionnaire (see Q1.1 in table 1 in Appendix), most of the respondents indicate that the active participation of the citizens in the development of the smart city is relevant. Nonetheless the model of participation is not clear. This way, both selected and open participation models obtain the same results and no preference is shown among respondents (the $51 \%$ of the respondents indicate the need of the participation of stakeholders with a mean score of each one of the participation models: 0,48; median score: 0 ). It means that smart city practitioners do assign relevance for citizens to actively participate in the management of the smart city, although it seems that they advocate the collaborative models, asking for citizens their help and suggestions to take decisions in the city (see Q1.1 in table 1 in Appendix). By contrast, the $3,12 \%$ of the respondents indicated that local governments should manage the development of smart cities without the participation of stakeholders (mean score: 0,03; median score: 0). This way, a question arises: How are local governments managing the citizen involvement in the smart cities? Which tools are they implementing or using in smart cities -Web 2.0, living labs, etc.-?

On another hand, table 2 in Appendix shows the variables and method of evaluation used in our observation of official webpages of the selected sample of smart cit- 
ies, and tables 3 and 4 in Appendix collects the results obtained in the examination of 85 local governments of smart cities (see section 3.1.).

Results show that 54 of the 85 sample smart cities offer a transparency website or an open data platform for information transparency $(63,52 \%$ of the total population in our study). Besides, 6 of the 11 smart cities that offer transparency websites also provide open data platforms. Indeed, in general, it seems clear that open data platforms are more frequent in these smart cities (49 of 85 smart cities provide it).

Regarding the information disclosed, whereas sample cities disclose organisational structure, human resources, public procurement, budgetary information, legislations and environmental information in transparency websites, the information disclosed in open data portals are usually addressed to put available information about transport/traffic, cultural activities and leisure, libraries/education, housing and environment, parking areas, job information and tourism.

On the other hand, the information format in which the information is disclosed is also relevant for information transparency [22], because if the information disclosed can be manipulated, it could help governments to encourage more civic engagement among citizenry. JavaScript Object Notation (JSON), eXtensible Markup Language (XML), Microsoft Excel or Comma Separated Values (CSV) formats are examples of generally-accepted spread-sheet formats that could help users to create their own reports. Table 3 in Appendix shows that smart cities are promoting information transparency facilitating citizens the manipulation of the information disclosed. Indeed, the main information format used is the CSV format, followed by JSON format and XML formats which offer citizens the opportunity to manipulate raw data for creating their own reports according to their needs. Also, smart cities with open data platforms usually offer the information to be downloaded in two or three information formats analysed in this paper (mainly csv and json information formats) -see table 3 in Appendix-, and only 12 sample cities (or 6 of the respondents that are included in the previously mentioned groups of EUROCITIES network) offer only one of the information formats analysed in this paper -see table 3 in Appendix-.

By contrast, sample smart cities are not fostering the citizen involvement in public affairs because only 38 of 85 sample smart cities $(44,71 \%)$ have a specific citizen participation platform website for public consultations, discussions or petitions to the local government of the city -see table 4 in Appendix-. Nonetheless, the most of them usually provide a specific link to contact with the government, either through web forms or through email addresses (81 of 85 for sample smart cities -95,29\%-). These percentages are even inferior in the particular case of those smart cities that responded the questionnaire -see table 4 in Appendix-.

However, it is also worthy to note that the $33,33 \%$ of sample cities with an eparticipation platform allows citizens to actively participate in public consultations, discussions and petitions, although public consultation is the most offered option in these web portals $(31,76 \%)$. This situation is similar among the cities that responded the questionnaire (only 32 smart cities are those included in the previously mentioned groups of EUROCITIES network) but they are also prone to offer citizens to make petitions. Also, a great deal of smart cities that offer a citizen participation platform website also provide the possibility to contact with the local government. So, it seems 
that the contact with the government is a possibility that is always offered by those smart cities that foster active citizen participation in the municipality.

In resume, results indicate that smart cities are promoting information transparency [23] because they are disclosing a great deal of information with the use of easily manipulated information formats but they are failing in facilitating the active participation of citizens nowadays.

\subsection{Selected or open stakeholder participation models of governance as indicators for offering information transparency and active participation}

Table 5 in Appendix shows the contingency tables between each one of the technological tools used for information transparency or active participation, and the responses that representatives of local governments have pointed out regarding the governance model to be implemented in their smart city.

As for information transparency, table 5 shows that although representatives of local governments in smart cities think that selected stakeholder or open participation are the best governance models to be implemented in their cities, they do not assign relevance in creating transparency websites or open data portals to disclose information. This result is especially true for the particular case of the offering of transparency websites. This way, the Pearson Chi-square test indicate that for both the creation of transparency websites or the creation of open data portals, RQ2 is not supported because statistical results are not significant.

By contrast, contingency tables seem to indicate an association between the offering of contact with the government and the intention to implement selected stakeholder or open participation governance models. Nonetheless, the results of the Pearson Chi-square are not significant again. Nonetheless, we can assume that the more participative model of governance, the higher offer of smart cities to contact with the city government.

Finally, similar to the result obtained for the information transparency case, there is no preference in creating e-participation platforms in the smart cities whose representatives have responded that selected stakeholder or open participation models are those to be implemented in their cities. Therefore, Pearson Chi-square does not support results and null hypothesis (RQ3) cannot be rejected.

\section{Conclusions}

Under the smart cities framework, the public value creation is linked to the satisfaction of citizenry's needs through the creation and use of smart technologies to increase their quality of life [1]. This research explores the relationship between the perception of smart practitioners about the model of citizen participation and the use of new technologies by city governments with the aim at improving e-participation of the citizenry in cooperative environments of smart cities. Findings based on smart city practitioners suggest the need to allowing citizens to actively participate in the city, mainly in the development of innovative ways to empower citizens and encourage 
civic engagement. So, cooperation and collaboration with service stakeholders must be encouraged, within and outside organizational boundaries [19].

The behaviour expressed in this research by smart practitioners could be explained because the organizing capacity of a city government is often viewed in terms of internal organization but the creation of public value in smart cities demand local governments to advance to a higher transformative level of governance, called as smart urban collaboration [15], which is based not only on the transformation of the internal organization but also of the external organization [15].

Therefore, a main challenge in smart cities is concerned with understanding how to design tools to facilitate online deliberation and support collaborative working environments. Nonetheless, according to our results, sample smart cities in our study are not promoting active participation of citizens. In fact, our results indicate that sample smart cities do not generate virtual environments for information transparency or for favouring fluid interaction between local governments and citizens. Hypotheses testing and contingency tables confirm that smart practitioners are prone to introduce open governance models but their smart cities are not putting available technological tools for achieving that aim. Thus, it is time to take steps from "intentions" to "actions". Perhaps a more active citizenship could help to demand smart cities to be more open o their queries and participation.

To achieve this aim, it is necessary to create a culture of citizen participation in public decisions. Citizens must be also smart and problems of digital divide should be solved in all cities. Recent research has found that governments are able to advocate and educate their citizens by communicating electronically with them and thus change their behaviours and attitudes toward the society [7]. So, smart cities must not only invest on ICT infrastructure, but also on staff training, human capital/education, social and relational capital, and environmental interest as important drivers of urban growth [2]. So, future research should tackle all these problems and explore the causes why citizens are not participating in cities where all aspects of open government are accomplished. Perhaps the reason is the lack of interest in participating in decisionmaking processes [24], the lack of technological tools to do it or the complexity of eparticipation platforms to make them involved in these processes. Also, future research could be addressed to analyse whether smart cities are promoting, or not, eparticipation in a higher level than those cities that cannot be labelled as smart. This way, we could advance better in the definition of smart cities and in the axes in which they are built on.

In conclusion, findings confirm that there is a dominant belief that transformation of governance is desirable and needed to make cities smart and to create public value, which promotes the use of new technologies to adopt a more participative model of governance [15]. Nonetheless, for truly effective local governance, it is essential that public managers and politicians not only govern efficiently, but that they put available technological tools for engaging citizens in open and participative information sharing and decision-making. This is a main challenge for governments in the nearer future. 


\section{Acknowledgments}

This research was carried out with financial support from the Regional Government of Andalusia (Spain), Department of Innovation, Science and Enterprise (Research project number P11-SEJ-7700).

\section{References}

1. Berntzen, L., Johannessen, M. R.: The role of citizen participation in municipal smart city projects: Lessons learned from Norway. In Smarter as the New Urban Agenda, pp. 299314. Springer International Publishing (2016).

2. Caragliu, A., Del Bo, C., Nijkamp, P.: Smart Cities in Europe. Journal of Urban Technology 18(2), 65-82 (2011).

3. Considine, M., Lewis, J.: Governance at ground level: The front-line bureaucrat in the age of markets and networks. Public Administration Review 59(6), 467480 (1999).

4. Dameri, R. P., Negre, E., Rosenthal-Sabroux, C.: Triple Helix in Smart cities: a literature review about the vision of public bodies, universities, and private companies. In System Sciences (HICSS), 2016 49th Hawaii International Conference on Systems Sciences, pp. 2974-2982. Hawaii, USA: IEEE (2016).

5. EUROCITIES (2016). Eurocities Strategic Framework 2014-2020. Towards an urban agenda for the EU. Brussels: Eurocities.

6. EUROCITIES (2017). About us. Available at: http://www.eurocities.eu/eurocities/about_us, last accessed 2017/2/1.

7. Feeney, M. K., Brown, A.: Are small cities online? Content, ranking, and variation of US municipal websites. Government Information Quarterly 34(1), 62-74 (2017).

8. Florida, R.: The rise of the creative class: and how it is transforming work, leisure, community and every- day life. Basic Books, New York, USA (2002).

9. Gascó, M.: Living labs: Implementing open innovation in the public sector. Government Information Quarterly 34(1), 90-98 (2017).

10. Giffinger, R., Gudrun, H.: Smart cities ranking: an effective instrument for the positioning of the cities? ACE: Architecture, City and Environment 4(12), 7-26 (2010).

11. Gil-García, J. R., Pardo, T. A., Nam, T. A.: Comprehensive view of the 21 st century city: Smartness as technologies and innovation in urban contexts. In Smarter as the New Urban Agenda, pp. 1-19. Springer International Publishing (2016).

12. Khodabakhsh, P., Fathi, H., Mashayekhi, S.: Planning for Future Urban Services in the Smart City Era: Integrating E-services in Urban Planning Process. Armanshahr Architecture \& Urban Development 9(16), 153-168 (2016).

13. Lee, S.: Creative citizenship and the public policy process: A flibbertijibbet, a will-o-the-wisp, a clown? Cultural Science Journal 8(1), 85-90 (2015).

14. Mainsah, H. N.: Social media, design and creative citizenship: an introduction. Digital Creative 28(1), 1-7 (2017). 
15. Meijer, A., Rodríguez Bolívar, M. P.: Governing the smart city: a review of the literature on smart urban governance. International Review of Administrative Sciences 82(2), 392-408 (2016).

16. Moore, M. H.: Creating public value: Strategic management in government. Harvard university press (1995).

17. Pierre, J.: Comparative urban governance: Uncovering complex causalities. Urban affairs review 40(4), 446- 462 (2005).

18. Rodríguez Bolívar, M. P.: The influence of political factors in policymakers' perceptions on the implementation of Web 2.0 technologies for citizen participation and knowledge sharing in public sector delivery. Information Polity 20(2, 3), 199-220 (2015a).

19. Rodríguez Bolívar, M. P.: Policy makers' perceptions on the transformational effect of Web 2.0 technologies on public services delivery. Electronic Commerce Research, 1-28 (2015b).

20. Rodríguez Bolívar, M. P.: Characterizing the role of governments in smart cities: A literature review. In Smarter as the new urban agenda pp. 49-7, Springer International Publishing (2016).

21. Rodríguez Bolívar, M. P.: Policy makers' perceptions on the transformational effect of Web 2.0 technologies on public services delivery. Electronic Commerce Research 17(2), 1-28. (2017).

22. Rodríguez Bolívar, M. P., Alcaide Muñoz, L., López Hernández, A. M.: Scientometric Study of the Progress and Development of e-Government Research during the Period 2000-2012. Information Technology for Development 22(1), 3674. (2016).

23. Gramberger, M.: Citizens as Partners OECD Handbook on Information. Consultation and Public Participation in Policy-making. Organization for economic cooperation and development, Paris (2001).

24. Hibbing, J. R., Theiss-Morse, E.: Stealth democracy: Americans' beliefs about how government should work. Cambridge University Press (2002).

25. Rodríguez Bolívar, M. P.: Governance models for the delivery of public services through the web 2.0 technologies: A political view in large Spanish municipalities. Social Science Computer Review 35(2), 203-225. (2017).

26. European Commission: Europe for citizens. Brussles, version valid as of 2017 (2017).

27. Denters, B.: Participation and democratic accountability: Making a difference for the citizens. In The Future of Local Government in Europe (pp. 79-100). Nomos Verlagsgesellschaft mbH \& Co. KG. (2017).

28. Snedecor, G. W. Cochran, W. G.: Statistical methods. The Iowa State University Press, Iowa (1981).

29. Sprent, P., Smeeton, N. C.: Applied nonparametric statistical methods Chapman \& Hall/CRC, Taylor \& Francis Group LLC, Boca Raton (2007). 


\section{APPENDIX}

Table 1. Descriptive statistics of questionnaire results.

\begin{tabular}{|c|c|c|c|c|c|c|c|c|c|c|c|c|c|}
\hline & & \multicolumn{12}{|c|}{ Descriptirie statisticic of the responses to the e-surrery } \\
\hline RQ1. Do goveremments promotet the collaboratitive or participative models of & Questi & \multicolumn{6}{|c|}{ Frequency } & \multirow[t]{2}{*}{ Mean } & \multirow[t]{2}{*}{ Median } & \multirow[t]{2}{*}{ Mode } & \multirow{2}{*}{$\begin{array}{l}\text { Standard } \\
\text { Deriation }\end{array}$} & \multirow[t]{2}{*}{ laximu } & \multirow[t]{2}{*}{ Vinimun } \\
\hline Q1.1. The model of participation in developing the smart city in juor municipalitivi s... & & No & $\%$ & Yes & $\%$ & Total & & & & & & & \\
\hline a) Exclusively the municipality. Noparticipation of other actors. & & 62 & $96,88 \%$ & 2 & $3,13 \%$ & 64 & $100,00 \%$ & 0,0313 & 0 & 0 & 0,1754 & 1 & 0 \\
\hline b) Selected Stakeholder participation. & & 33 & $51,56 \%$ & 31 & $48,44 \%$ & 64 & $100,00 \%$ & 0,4844 & 0 & 0 & 0,5037 & 1 & 0 \\
\hline c) Open participation. & & 33 & $51,56 \%$ & 31 & $48,44 \%$ & 64 & $100,00 \%$ & 0,4844 & 0 & 0 & 0,5037 & 1 & 0 \\
\hline
\end{tabular}

Source: Own elaboration.

Table 2. Analysis performed in this research. Variables and method of evaluation.

\begin{tabular}{|c|c|c|c|c|c|}
\hline Area of Analysis & Stages Analyzed & lems & Description & Type of analysis & Sore \\
\hline \multirow{4}{*}{ EPParticiption } & \multirow{2}{*}{ Iffomation Trasspadeny } & Webof fraspranany & 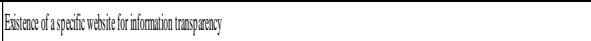 & puratiditie & $\mathbb{Q 1}$ \\
\hline & & Opendadal Ilesite & 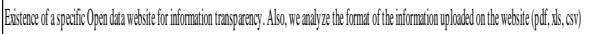 & Quantitinie & $\mathbb{N 1}$ \\
\hline & \multirow{2}{*}{ Adtive Partication } & Cotizen Participation Plaffom & 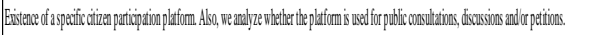 & puantiditie & $\mathbb{N 1}$ \\
\hline & & Contad with the Government & 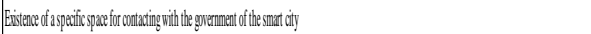 & Quanitidive & $\mathbb{M}$ \\
\hline
\end{tabular}

Surre: One elaboration.

Table 3. Transparency websites and open data websites in total sample population and respondents to the e-survey.

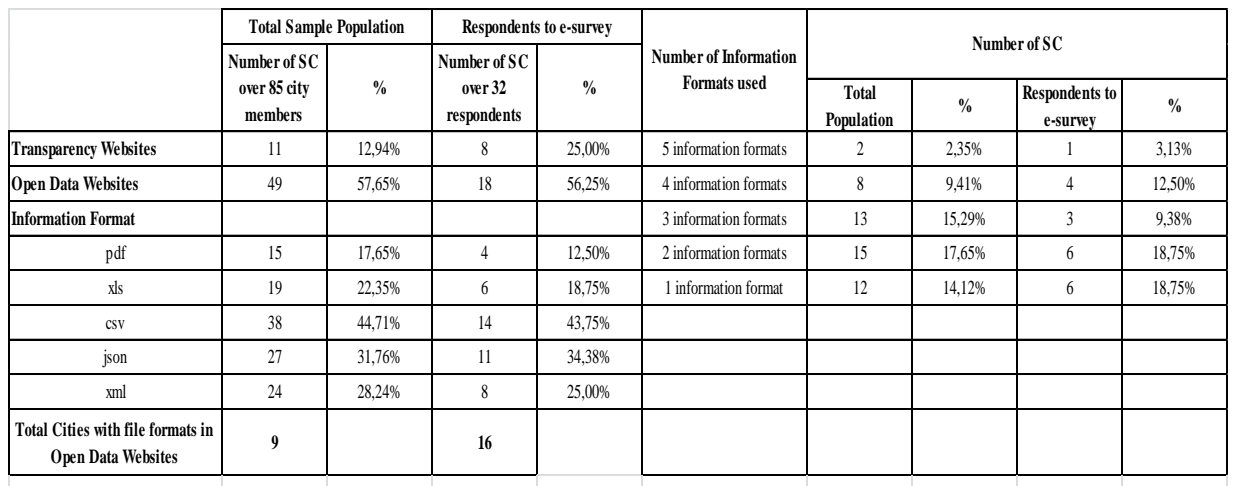

Source: Own elaboration. 
Table 4. E-participation tools used in total population and respondents to the esurvey.

\begin{tabular}{|c|c|c|c|c|c|c|c|c|c|c|c|c|c|}
\hline & \multicolumn{2}{|c|}{ Total Population } & \multicolumn{2}{|c|}{ Respondents to e-survey } & \multirow{2}{*}{\multicolumn{3}{|c|}{$\begin{array}{l}\text { Aspects deal with into the citizen participation platform } \\
\text { weebsite }\end{array}$}} & \multicolumn{6}{|c|}{ Number of smart cities } \\
\hline & \multirow{2}{*}{$\begin{array}{c}\text { Numberof SC } \\
\text { orer 85 city } \\
\text { members }\end{array}$} & \multirow[b]{2}{*}{ Yoter 85} & \multirow{2}{*}{$\begin{array}{c}\text { Number of SC } \\
\text { orer } 32 \\
\text { respondents }\end{array}$} & \multirow[b]{2}{*}{$\%$} & & & & \multirow{2}{*}{$\begin{array}{c}\text { Total } \\
\text { Popplation }\end{array}$} & \multirow[b]{2}{*}{ \% Total } & \multirow{2}{*}{ Fover 85SC } & \multirow{2}{*}{$\begin{array}{c}\text { Respondents to } \\
\text { e-sururey }\end{array}$} & \multirow[b]{2}{*}{ \% Total } & \multirow[b]{2}{*}{ Forer 3250 } \\
\hline & & & & & Public consultations & Discussions & Petitions & & & & & & \\
\hline Citizen participation platform website & 38 & $44,71 \%$ & 6 & $18,75 \%$ & $x$ & $x$ & $x$ & 13 & $33,33 \%$ & $15,29 \%$ & 3 & $27,27 \%$ & $9,38 \%$ \\
\hline \multirow[t]{2}{*}{ Contact with the loal government } & 81 & $95,29 \%$ & 15 & $46,88 \%$ & $x$ & $x$ & & 4 & $10,26 \%$ & $4,71 \%$ & 1 & $9,09 \%$ & $3,13 \%$ \\
\hline & & & & & & $x$ & $x$ & 4 & $10,26 \%$ & $4,71 \%$ & 3 & $27,27 \%$ & $9,88 \%$ \\
\hline Aspects into participation plaffoms & & & & & $X$ & & $X$ & 2 & $5,13 \%$ & $2,35 \%$ & 0 & $0,00 \%$ & $0,00 \%$ \\
\hline Public consulatition & 6 & $7,06 \%$ & & & $x$ & & & 9 & $23,18 \%$ & $10,59 \%$ & 2 & $18,18 \%$ & $6,25 \%$ \\
\hline Disausions & 6 & $7,06 \%$ & & & & $x$ & & 3 & $7,69 \%$ & $3,35 \%$ & 2 & $18,18 \%$ & $6,25 \%$ \\
\hline Petifitions & 13 & $15,29 \%$ & & & & & $X$ & 4 & $10,26 \%$ & $4,71 \%$ & 0 & $0,00 \%$ & $0,00 \%$ \\
\hline
\end{tabular}

Source: Own elaboration.

Table 5. Contingency tables and hypothesis testing.

\begin{tabular}{|c|c|c|c|c|c|c|c|c|c|}
\hline \multirow{2}{*}{\multicolumn{3}{|c|}{ Attribute/E-survey model of Governance }} & \multicolumn{4}{|c|}{ The model of participation in developing the smart city in your municipality is ... } & \multicolumn{3}{|c|}{ Pearson Chi-Square } \\
\hline & & & \multirow{2}{*}{\begin{tabular}{|c|}
$\begin{array}{c}\text { Exclusively the municipality. No } \\
\text { participation of other actors }\end{array}$ \\
1 \\
\end{tabular}} & \multirow{2}{*}{\begin{tabular}{|c|}
$\begin{array}{c}\text { Selected Stakeholder } \\
\text { participation }\end{array}$ \\
12 \\
\end{tabular}} & \multirow{2}{*}{\begin{tabular}{|c|}
$\begin{array}{c}\text { Open } \\
\text { participation }\end{array}$ \\
11 \\
\end{tabular}} & \multirow{2}{*}{$\begin{array}{c}\text { Total } \\
24 \\
\end{array}$} & \multirow{2}{*}{$\frac{\text { Value }}{605 a}$} & \multirow{3}{*}{$\frac{\text { Df }}{2}$} & \multirow{2}{*}{$\frac{p \text { (2-sided) }}{0,738953}$} \\
\hline \multirow{4}{*}{ Information transparency } & The Smart City has & $\mathrm{N}_{0}$ & & & & & & & \\
\hline & a government & Yes & 0 & 5 & 3 & 8 & ,605a & & 0,738953 \\
\hline & The Smart City has & $\mathrm{N}_{0}$ & 1 & 8 & 8 & 17 & \multirow{2}{*}{$1,224 a$} & \multirow{2}{*}{2} & \multirow{2}{*}{0,5421784} \\
\hline & an open government & Yes & 0 & 9 & 6 & 15 & & & \\
\hline \multirow{4}{*}{ Active participation } & The Smart City & $\mathrm{N}_{0}$ & 0 & 1 & 0 & 1 & \multirow{2}{*}{,91la } & \multirow{2}{*}{2} & \multirow{2}{*}{0,6341892} \\
\hline & offers the posibility & Yes & 1 & 16 & 14 & 31 & & & \\
\hline & \multirow{2}{*}{\begin{tabular}{|c|c|} 
The Smart City has & \multicolumn{1}{|c|}{ a citizen } \\
\cline { 2 - 2 }
\end{tabular}} & $\mathrm{N}_{0}$ & 1 & 8 & 10 & 19 & \multirow{2}{*}{$2,597 \mathrm{a}$} & \multirow{2}{*}{2} & \multirow{2}{*}{0,2730041} \\
\hline & & Yes & 0 & 9 & 4 & 13 & & & \\
\hline & & Total & 4 & 68 & 56 & 128 & & & \\
\hline
\end{tabular}

a. 2 casillas $(33,3 \%)$ tienen una frecuencia esperada inferior a 5 . La frecuencia mínima esperada es ,41.

Source: 0 wn elaboration. 